\title{
Drought Adaptation and Coping Strategies Among the Turkana Pastoralists of Northern Kenya
}

\author{
Francis Opiyo $^{1,2} \cdot$ Oliver Wasonga $^{1} \cdot$ Moses Nyangito $^{1} \cdot$ Janpeter Schilling $^{3} \cdot$ \\ Richard Munang ${ }^{4}$
}

Published online: 16 September 2015

(C) The Author(s) 2015. This article is published with open access at Springerlink.com

\begin{abstract}
This study highlights drought characteristics and the many responses to drought stresses employed by Turkana pastoralists of northwestern Kenya. Multiple data sources, including socioeconomic interviews with 302 households, focus group discussions, and informal interviews with pastoralists were used to capture various aspects of drought and drought adaptation and coping practices. Standardized precipitation index derived from long-term rainfall data obtained from the Kenya Meteorological Service was used to quantify different degrees of drought intensity between 1950 and 2012. Results revealed that extreme drought events were increasingly frequent, and have impacted negatively on pastoral livelihoods. In order to adapt to or cope with climatic anomalies, households are using a variety of strategies. In addition to the traditional short-term coping mechanisms, the long-term adaptation strategies used include diversification of livelihood sources; livestock mobility to track forage and water resources; diversification of herd composition to benefit from the varied drought and disease tolerance, as well as fecundity of diverse livestock species; and sending children to school for formal education as a long term investment expected to pay back through income from employment. Policies and
\end{abstract}

Francis Opiyo

francis.opiyo@undp.org

1 Department of Land Resource Management and Agricultural Technology, University of Nairobi, Nairobi 00625, Kenya

2 United Nations Development Programme (UNDP), Global Policy Centre, Nairobi 00100, Kenya

3 International Alert, Environment, Climate Change and Security Program, London SW9 9AP, UK

4 United Nations Environment Programme (UNEP), Regional Office for Africa, Nairobi 00100, Kenya development interventions that reduce risks, diminish livelihood constraints, and expand opportunities for increased household resilience to drought are critical complements to the existing pastoral strategies.

Keywords Adaptive capacity - Climate change . Pastoralism · Resilience · Turkana

\section{Introduction}

Drought is often one of the most devastating but least understood weather phenomena, largely because of its slow onset and its accumulating impacts over time. Although definitions vary depending on the context, drought is generally an extended period of months or years in which precipitation is less than the annual average and results in severe water scarcity (Wilhite 2000; Downing and Bakker 2000; Whetherald and Manabe 2002). According to the World Meteorological Organization (Hounam et al. 1975), droughts are classified as either meteorological (lack of precipitation over a region for a period of time), hydrological (a period with inadequate surface and subsurface water resources), agricultural (a period with declining soil moisture and consequent crop failure due to lack of surface water resources), or socioeconomic (failure of water resources systems to meet demands, which impacts human activities both directly and indirectly). The Kenya Meteorological Service (2010) defines normal meteorological drought as a situation in which rainfall over an area is less than $75 \%$ of the climatological normal (that is, a rainfall deficiency of at least $25 \%$ ). This definition is extremely crude as it gives little information about the temporal distribution of rainfall (Wilhite and Glantz 1985). On the other hand, one could define optimal rainfall as sufficient 
rainfall in amount and distribution over time and space to meet the needs of specific livelihoods. For the Horn of Africa region, drought occurrence has become increasingly severe during the last decade, with rainfall totals of at least $50-75 \%$ below normal encountered in most areas, amounts that are not sufficient to support crop and pasture growth for livelihood security (Nicholson 2014). Studies by Huho and Mugalavai (2010) and Nkedianye et al. (2011) indicate that Kenya has experienced an increase in drought frequency from once in every 10 years in the $1960 / 70$ s to once in every 5 years in the 1980 s; the frequency of drought increased to once in every $2-3$ years in the 1990s, and has become increasingly unpredictable since 2000. According to the report of the Intergovernmental Panel on Climate Change (IPCC 2012), there is likely to be a marked increase in drought risk over much of Eastern Africa by the 2050s, which ultimately will threaten climate sensitive economic sectors.

Studies show that drought poses serious challenges for populations whose livelihoods depend principally on natural resources (Below et al. 2010; Nicholson 2014). Kenya's arid and semiarid lands (ASALs), which have faced increasing drought frequency and intensity since the $1960 \mathrm{~s}$, are one of the most vulnerable and drought-prone regions in the country (Nkedianye et al. 2011). Despite this exposure and sensitivity to frequent droughts, pastoral economy in the ASALs' of Kenya accounts for $90 \%$ of all employment opportunities and $95 \%$ of family income and livelihood security (Kenya ASAL Policy 2012). Given the changing global climate, coupled with expected increase in evapotranspiration due to increased temperatures, the ASALs are expected to experience frequent climatic extremes, increased aridity, increased water stress, diminished yields from rain-fed agriculture, and increased food insecurity and malnutrition (Thornton and Lipper 2014). Adaptation and coping practices are therefore necessary to reduce vulnerability to drought stresses as well as to prepare for possible future extreme climate events. The Intergovernmental Panel on Climate Change reports (IPCC 2001, 2007, 2012) define adaptation as an adjustment in natural or human systems in response to actual or expected climatic stimuli or their effects, which moderates harm or exploits beneficial opportunities. Adaptation therefore involves adjustments in reducing the vulnerability of households to climatic variability and change (Adger et al. 2007). On the other hand, Blaikie et al. (1994) define coping as the manner in which people act within existing resources and ranges of expectation in a given context to achieve various ends. Therefore, adaptation involves longer-term shifts in livelihood strategies, while coping involves temporary adjustment in response to change or to mitigate shocks and stresses on livelihoods (Eriksen et al. 2005; Migosi et al. 2012). However, adaptation or coping mechanisms of people to different hazards vary from household to household and region to region based on existing support systems that increase the resilience of affected individuals (Brooks et al. 2005).

The adaptation strategies of pastoral communities to changing environmental conditions have been studied for decades (Gulliver 1955; Saitoti 1986; Ellis 1995; Campbell 1999; McCabe 2006). This literature show that the livelihoods of most pastoralists have evolved to some extent under variable climatic conditions in arid and semiarid environments (Blench 2000; Little 2003; Notenbaert et al. 2007; Thornton and Gerber 2010). The African Union (2010, p. 21) reports that pastoralism has "evolved over generations as a response to marked rainfall and temperature variability," and that flexible and mobile pastoralism has great potential for reducing poverty, generating economic growth, managing the environment, and promoting sustainable development. Other research has shown that pastoralists have an intimate relationship with their environment and a rich knowledge that enables them to both protect and exploit the changing rangeland conditions on which they depend (McGahey et al. 2008; Notenbaert et al. 2012). Understanding how pastoral communities adapt to and cope with extreme climatic conditions, particularly drought, becomes even more important as pastoralism in northwestern Kenya already faces environmental, political, and socioeconomic marginalization (Schilling et al. 2012).

The recent discovery of oil in Turkana is likely to pose a threat to pastoralist resilience to drought if appropriate measures are not put in place (Opiyo 2012). Eliza et al. (2015) indicate that the oil discovery will exacerbate preexisting tensions and likely result in full-blown violent conflicts among the Turkana's and foreign investors such as Tullow Oil. That notwithstanding, the oil discovery offers development opportunities in the area mainly in the form of a new road network and employment for the local community. Oil-driven development has the potential to open up northern Kenya and integrate it into the national, regional, and international economy. However, recent developments such as fencing off large tracts of grazing land for proprietary oil exploration has already constrained herd mobility, which is a key drought coping strategy and therefore the main tenet of the pastoral production system in the area. A few recent studies (Speranza 2010; Silvestri et al. 2012; Osano et al. 2013) have endeavored to document pastoralists' adaptation and coping strategies to the complexity of drought at a microscale before the issue of oil development arose. Given the projections for increasing drought impacts in the pastoral areas and other social pressures, it is important to document various adaptation and coping responses at local levels in order to reduce risks associated with recurrent droughts. 
This study sets out to examine drought characteristics, identify adaptation processes more broadly as long-term mitigation measures, and analyze temporary coping responses to drought in northwestern Kenya. Knowledge about pastoralists' adaptation and coping responses to drought stresses can guide possible intervention measures, as well as better inform policy designed to reverse the decline in pastoral production systems, and hence ensure continued sustainability of rural livelihoods in arid and semiarid environments.

\section{Study Area}

The study was conducted in Turkana County of northwestern Kenya. This region is characterized by a topographically varied, semiarid to arid landscape and livelihood activities are exposed to a significant drought risk. Traditional nomadic animal husbandry has been the dominant economic activity for centuries.

\subsection{Geographical Setting}

Low-lying plains with isolated mountains and ranges of hills dominate the western part of the county (Fig. 1). Turkana County ranges in altitude from 369 m near the shores of Lake Turkana to $900 \mathrm{~m}$ at the foot of escarpment near the Ugandan border to the west. According to the 2009 census report, the Turkana population stands at 855,399 , or $2.5 \%$ of Kenya's total population (Kenya National Bureau of Standards 2010). Rainfall is bimodal, highly variable in space and time, with a long-term mean of $216 \mathrm{~mm}$. The region is characterized by frequent drought events from 1950-2012, with generally below-average annual precipitation (Fig. 2). Annual mean maximum temperatures experienced in the study area range between 23 and $38{ }^{\circ} \mathrm{C}$ with a long-term mean of $30^{\circ} \mathrm{C}$. The northern part towards southern Sudan and Ethiopia is more arid than the western region towards Uganda, which is semiarid. Turkana County lies in agroecological zones (AEZ) IV (Semihumid to Semiarid) and V (Semiarid) (Jaetzold and Schmidt 1983), and is hot and dry throughout most of the year.

The vegetation is widely varied and ranges from patchy annual grassland and herbaceous plants interspersed with woody shrubs to riverine woody trees species, although most parts of the district have dwarf shrubs and bush species. The density of plants, such as Acacia reficiens and A. mellifera, increases as one moves away from the settlement areas, especially in poor range conditions where soil moisture is more limited (Kariuki et al. 2008). A. reficiens and A. mellifera are both dominant and critical to pastoralists in the study area. The dominance of these tree species may have been favored by their tolerance to range

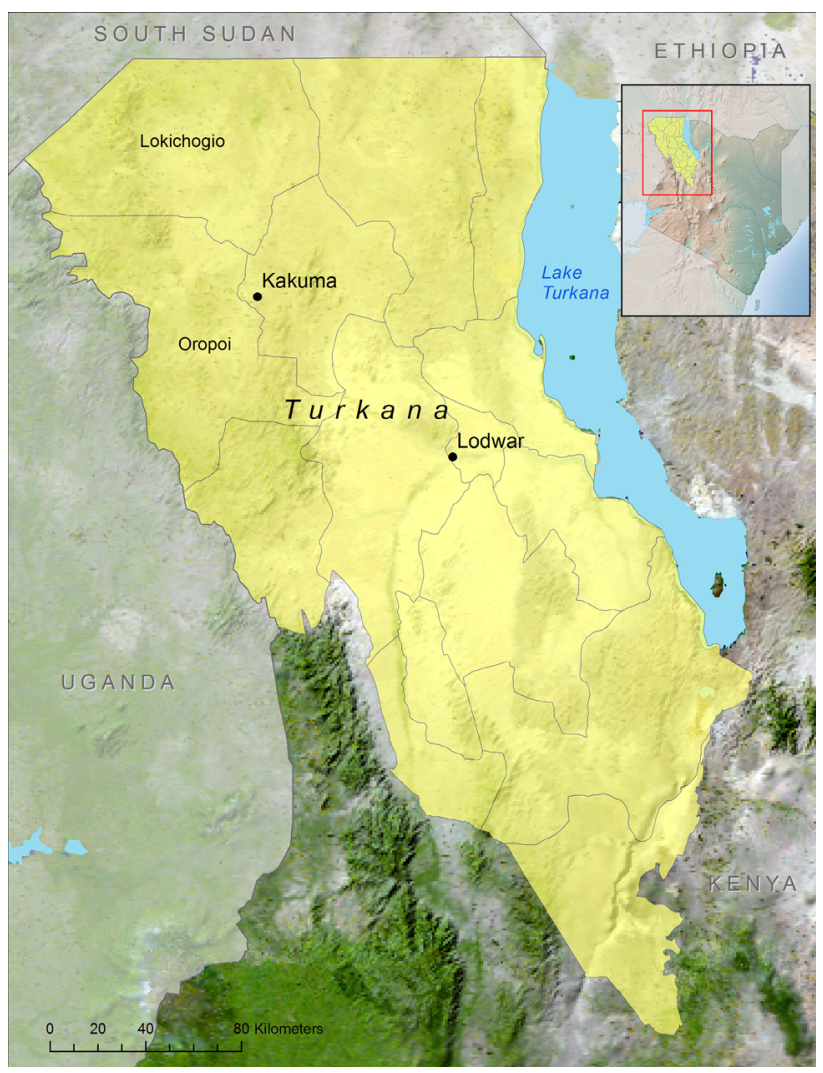

Fig. 1 Location of Lokichogio, Kakuma, and Oropoi in Turkana County. Source Adapted from World Countries Layer (http://www. arcgis.com/home/item.html?id=

3864c63872d84aec91933618e3815dd2)

soil and deep root systems for accessing soil moisture. Both plant species produce leaves and seed pods that contain (relatively speaking) high protein and fiber content. The trees are preferred by goats and camels as browse resource, and play a critical role during drought conditions. A. mellifera is also considered a good honey bee (Apis mellifera) forage and used for construction of livestock bomas ${ }^{1}$ and fencing; they are also good firewood. Spatial profiling of vegetation in Turkana by Coughenour and Ellis (1993) indicates that woody species were dominated by $A$. tortilis in the riparian zones, with $A$. senegal mainly occurring on hilly and rocky sites, and $A$. reficiens on nonriparian sites with fine soils. A. tortilis is popular for its protein-rich pods locally known as sakaram that are particularly important in maintaining livestock body condition during droughts (Coughenour and Ellis 1993). The exotic Prosopis juliflora has increasingly become an important invader, especially on riverine floodplains, along road sides, and near human settlements. The increasing colonization of the grazing lands by $P$. juliflora if not well managed is likely to

\footnotetext{
${ }^{1}$ A booma is a fortified livestock enclosure build of thorny Acacia and other tree branches.
} 
Fig. 2 Percent deviation of mean annual rainfall based on 1950-2012 long-term mean $(215.7 \mathrm{~mm})$ in Turkana. Source Rainfall data accessed by the corresponding author from the Kenya Meteorological Service data records in Nairobi on 23 April 2013

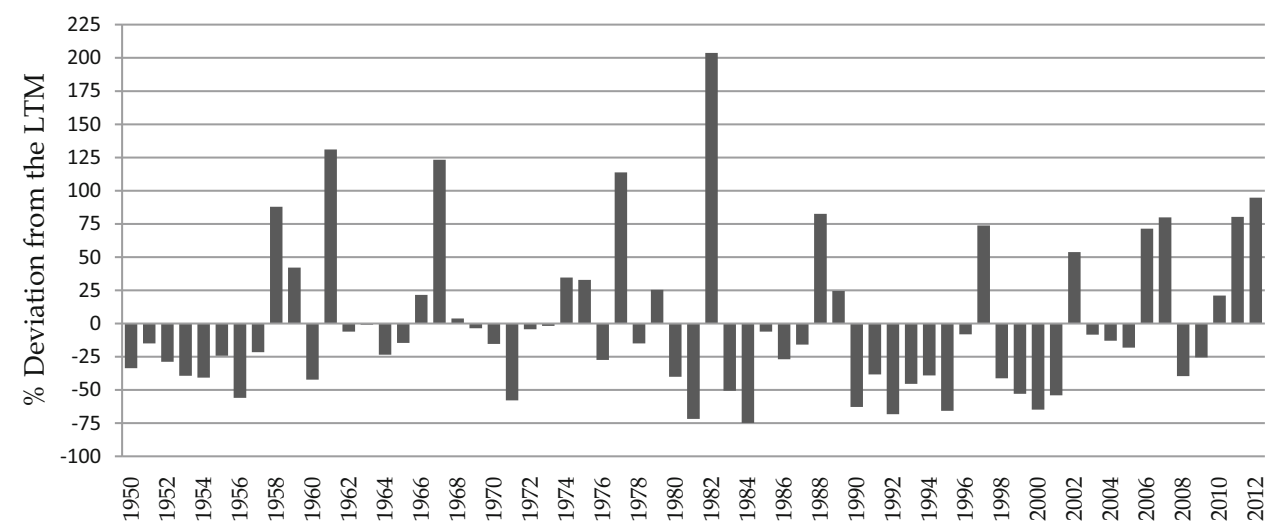

constitute an ecological and socioeconomic threat (Opiyo et al. 2014). Some of the deleterious effects of $P$. juliflora are caused by its ability to cast sufficient shade, which suppress undergrowth establishment, especially herbaceous species critical for livestock grazers, while also place high demands on water and nutrient capacities of the soil (Maundu et al. 2009).

In the study area, pastoralism is the predominant livelihood, and engages the attention of over $55 \%$ of the population, which is mainly pursuing extensive nomadic livestock rearing in communal open access rangelands (Opiyo et al. 2014). Most of the land in Turkana County is communally owned, which is an important strategy in support of effective drought adaptation and coping mechanisms. Recently efforts have begun to revise the land tenure system in Turkana to meet the needs of a variety of resource users, including changes associated with the discovery of oil in the area (discussed in Sect. 4.3.1). With land fragmentation, resource conflicts are likely to arise. For the Turkana pastoralist, the communal land tenure system is pivotal to livelihood security because it allows for livestock mobility to take advantage of pasture and water resources that are only seasonally accessible (Kameri-Mbote 2013). Turkana herders own a wide range of indigenous livestock species, which are selected on the basis of survival and productivity and are well adaptation to the prevailing climatic conditions (Notenbaert et al. 2007). The livestock species kept include camels, cattle, sheep, goats, and donkeys. Limited small-scale irrigated crop cultivation is spread along the riverine areas, and mainly is focused on growing sorghum, maize, green grams (mung beans), cowpeas, vegetables, watermelon, pumpkins, gourds, and bananas.

\subsection{The Turkana Pastoralists}

The Turkana, a Nilotic ethnic group, is the dominant community in the study area. Pastoralism is their principle livelihood and their nomadic system is believed to have evolved under variable climatic conditions, marked by multiple livelihood strategies deployed to meet changing environmental conditions (Blench 2000; Notenbaert et al. 2007). The Turkana people traditionally occupied 19 territories and were grouped into 28 small clans, each occupying a defined territory. For centuries, no individual rights to forage have existed, and crossing into or crossing over nearby grazing territories requires permission from the elders and the emuron (seer) of each territory. But even when observed rights of access to pasture and water exist, these traditional rights may not translate into secure access and use due to both threats of livestock raiding from neighboring communities and actual theft with violence. For example, the area around the village of Loya is a conflict hot spot between the Turkana and the Pokot, since both groups claim communal preferential access rights and try to enforce their authority (Schilling et al. 2012). Based on an analysis of a local conflict database, Schilling et al. (2014) report an average raiding frequency of six raids per month in Turkana between 2006 and 2009. The raids not only cause human suffering directly, but they also impact negatively on household adaptation and coping strategies of herding units in the raided area (Bett et al. 2009).

Turkana pastoralists, like other nomadic communities, have traditionally used risk-spreading strategies over the years that include moving livestock to access the best quality pasture and water available, keeping speciesspecific herds to take advantage of the heterogeneous nature of their disequilibrium environment, and diversifying economic strategies to include agriculture, wage labor, and beekeeping among others (Swift 2001; Watson and van Binsbergen 2006). Other strategies employed include keeping herds containing a mixture of different livestock species as insurance against total loss of livestock in case of drought. The livestock species kept include camels, cattle, sheep, goats, and donkeys, all of which have different forage and water requirements and variable levels of resilience to drought. The camels, cattle, and goats provide milk, which is consumed by the households. The small stock are sold when cash is required to meet other domestic requirements such as to purchase food or to pay school 
fees. For a long time, a majority of the Turkana community raised their livestock mainly to meet subsistence and sociocultural obligations. However, this practice has been changing in response to ecological and socioeconomic change dynamics (Schilling et al. 2012) as households increasingly embrace the market economy and offer more animals for sale than before.

\section{Research Design}

This section presents an overview of the study's research design in terms of the main datasets used, as well as their sources, types, and approaches for data analysis. A combination of quantitative and qualitative research methods was adopted to identify the drought adaptation and coping strategies used by the Turkana pastoralists. Long-term precipitation datasets were used to analyze drought severity, while field interviews were conducted with household respondents using semistructured questionnaires. To generate the qualitative data, the study employed key informant interviews and focus group discussions.

\subsection{Rainfall Data}

The data used in this study includes precipitation records from Lodwar station obtained from the Kenya Meteorological Service data records on 23 April 2013 in Nairobi, Kenya. The choice of Lodwar weather station was informed by the availability of reliable long-term and continuous record of rainfall data for the period under study. The precipitation datasets include observations spanning over six decades from 1950 to 2012, and thus more than enough to meet the 30 year minimum of continuous observations required for a valid climate statistical analysis (World Meteorological Organization 2009). The standardized precipitation index (SPI) was used to analyze drought severity. The SPI was calculated for 12 months (M12) for the period between January 1950 and December 2012. In the analysis, negative values of SPI are considered to represent dry periods and positive values reflect wet periods. The SPI has been used previously in Australia (Abawi et al. 2003), Mexico (Giddings et al. 2005), and parts of Kenya's ASALs (Huho and Mugalavai 2010) to examine drought severity. The SPI is computed by dividing the difference between normalized seasonal precipitation and its long-term seasonal mean by the standard deviation as follows:

$\mathrm{SPI}=\frac{\mathrm{x}_{i j}-x_{i m}}{\sigma}$

where $\sigma$ is the standard deviation, $x_{i j}$ is seasonal precipitation at the $i$ th synoptic station, $x_{i m}$ is long term seasonal mean precipitation.
Meteorological drought was considered to have occurred when the SPI value was negative and ended when the value became positive. Droughts were categorized as mild when the SPI value ranged from 0 to -0.99 ; moderate with a value from -1.0 to -1.49 ; severe when the value ranged from -1.5 to -1.99 ; and extreme when the value ranged from -2.00 and below. The normal mean precipitation is when SPI was zero (0.00).

\subsection{Sampling and Data Analysis Procedures}

This study used systematic and purposive sampling techniques to select drought-prone areas in Turkana County, which included Kakuma, Oropoi, and Lokichogio. In the sampled locations, households were relatively few and widely scattered, making accessibility a challenge considering the difficult terrain. Consequently, 10 homesteads $(a w i)^{2}$ were purposively selected based on accessibility from which households were randomly interviewed using a questionnaire. A total of 302 households were interviewed. Household interviews were supplemented by detailed conversations with 34 key informants from various organizations. In addition, 10 focus group discussions (FGDs) were conducted separately with equal gender presentation from the sampled homesteads.

A semistructured questionnaire with open-ended, multiple-response and dichotomous questions was used to collect data. A pilot test run was conducted with local enumerators prior to the main survey, and the final questions were amended based on enumerator feedback and analysis of informant responses to questions. The questionnaire interviews collected data on socioeconomic characteristics of households, which include gender, education, and age of the respondent, household size, farm and off-farm income activities, access to extension services, livestock ownership and production, information on climate, access to credit, social networks, and remittances. In addition, data were gathered on aspects of drought impacts and household adaptation and coping strategies. By employing qualitative methods, this study seeks to understand the experiences of drought-affected households, especially in terms of impacts and adaptation and coping strategies, employed before, during and after drought events. To avoid misinterpretation, the interviews and discussions were conducted in the local language generally understood by the respondents.

The collected data were coded and analyzed using STATA software (version 9.0) from StataCorp (2013). The software categorizes the respondents along according to socioeconomic characteristics, such as the number of cattle owned. Further, the tool was instrumental to identification

\footnotetext{
${ }^{2}$ The awi is the basic economic and management unit in Turkana.
} 
of the drought adaptation and coping strategies of households.

\section{Results and Discussion}

This section presents drought severity in the study area between 1950 and 2012. The perceived impact of drought on the pastoral production system is discussed. The article focuses on understanding drought severity at a temporal scale and drought impacts on pastoralist livelihood and the adaptation and coping strategies practiced by pastoralists. The study also examines the constraints faced by pastoral households that affect development and policy interventions aimed at enhancing pastoral livelihoods.

\subsection{Characterization of Drought}

In an arid to semiarid area like Turkana County, drought is a common phenomenon. However, previous studies suggest that drought frequency has increased, particularly in the past three decades (Huho and Mugalavai 2010). Increases in temperature and rainfall variability, associated with global climate change, are likely to further increase the drought risk in Turkana (Schilling et al. 2014). The present study utilizes the SPI to analyze drought severity in Turkana County. The analysis shows that severe and extreme meteorological droughts were experienced between 1950 and 2012 in the study area. Severe drought years were observed in 1955 , 1957, and 1964, while extreme droughts occurred in 1950, 1960, 1980, 1990, 1995, 2000, 2008, and 2009 (Table 1). More than $80 \%$ of the droughts that occurred in Turkana County were of large spatial extent, and also had widespread impacts in other parts of Kenya. These extreme conditions pose a major challenge to livelihood activities. Contrary to the conventional wisdom that 2010-2011 was the worst drought over the last 60 years in the region, Table 1 reveals that 2010-2011 was actually a normal to moderate rainfall period in Turkana.

SPI data confirms that some of the meteorological drought years match well with the historical records of actual droughts observed by the respondents. Thus, statistical counts of drought episodes from SPI values can be used to obtain the overall drought characteristics in the study area over time. The SPI analysis shows that extreme drought events have increased over the last 63 years, with $28.5 \%$ of drought occurrences falling in the two decades between 1950 and 1970 in contrast to $47.9 \%$ of drought years occurring in the study area during the last two decades between 1990 and 2012. It seems clear from the data presented and discussed here that drought is the absolute norm in Turkana territory and "good" or "normal" years are the abnormality.
The Drought Severity Index summation indicates that approximately $80 \%$ of prolonged droughts experienced between 1950 and 2012 were extreme, which further emphasizes the dominance of aridity in Turkana County. Extreme drought conditions have serious negative effects on the livelihood security of most pastoralists in Turkana. The concurrence of such droughts generally is associated with the El Niño Southern Oscillation (ENSO) phenomenon, which causes below normal rainfall in Kenya in general (Anyamba and Tucker 2001) and Turkana County in particular. Regional climate conditions are also thought to be influenced by anthropogenic impacts from land use changes, which affect vegetation cover, surface albedo, and soil moisture (Douville 2003). The increasing severity and frequency of occurrence of droughts is an indication that the region is getting drier and this change is reflected in the observed changes in arid northwestern Kenya. This observation concurs with Howden (2009), who also notes that climatic conditions in northern Kenya are getting drier.

\subsection{Impacts of Drought as Perceived by the Households}

Drought is expected to have significant impacts in most of the climate sensitive sectors in Kenya. In the ASALs, for example, frequent droughts are associated with the deterioration of livestock condition, increased incidences of certain diseases and livestock deaths, altered herd structure, and a collapse of livestock markets (Speranza 2010). As a result of frequent droughts, a high level of livestock mortality has become a norm in the study area (Table 2). Respondents cited the 2008 and 2009 drought years as the cause of the highest livestock mortality in Turkana, exceeding in destructiveness the 1980 and 1984 droughts. The survey results show that $22 \%$ of livestock mortalities were associated with starvation from drought events. Studies by Huho and Mugalavi (2010) and Nkedianye et al. (2011) reported a positive correlation between drought severity and the magnitude of livestock losses in northern Kenya. Further discussions with the key informants revealed that increased incidence of livestock disease was also partly associated with drought in Turkana. In contrast, studies by Catley et al. (2014) revealed that diseases such as Pest des Petits Ruminants (PPR) are not strongly associated with drought as perceived by the local herders. From an epidemiological perspective, the accurate measurement of livestock mortality in pastoralist areas during drought is problematic.

Respondents state that disease-related mortality accounted for the majority of small ruminants' deaths. Field observations also indicated that drought exacerbated existing resource-based conflicts between herding groups over water and pasture resources, which also resulted in 
Table 1 Meteorological drought severity in Turkana between 1950 and 2012

\begin{tabular}{|c|c|c|c|c|}
\hline Year & $\begin{array}{l}\text { Annual rainfall } \\
\text { total }(\mathrm{mm})\end{array}$ & $\begin{array}{l}\text { Standard } \\
\text { deviation }(\sigma)\end{array}$ & $\begin{array}{l}\text { Drought severity } \\
\text { index (SPI) }\end{array}$ & $\begin{array}{l}\text { Drought } \\
\text { category }\end{array}$ \\
\hline 1950 & 143.1 & 24.7 & -2.68 & Extreme \\
\hline 1955 & 163.3 & 20.2 & -1.94 & Severe \\
\hline 1960 & 124.7 & 15.4 & -3.37 & Extreme \\
\hline 1965 & 184.2 & 31.0 & -1.16 & Moderate \\
\hline 1970 & 182.7 & 26.2 & -1.22 & Moderate \\
\hline 1975 & 286.6 & 35.7 & 2.62 & Normal \\
\hline 1980 & 129.3 & 22.5 & -3.19 & Extreme \\
\hline 1985 & 202.5 & 26.2 & -0.49 & Mild \\
\hline 1990 & 80.2 & 8.1 & -5.01 & Extreme \\
\hline 1995 & 74.1 & 8.6 & -5.24 & Extreme \\
\hline 2000 & 75.9 & 12.7 & -5.27 & Extreme \\
\hline 2005 & 176.6 & 24.3 & -0.18 & Moderate \\
\hline 2006 & 369.8 & 44.0 & 5.70 & Normal \\
\hline 2007 & 388.0 & 31.1 & 6.37 & Normal \\
\hline 2008 & 130.2 & 16.7 & -3.16 & Extreme \\
\hline 2009 & 160.8 & 30.5 & -2.03 & Extreme \\
\hline 2010 & 261.2 & 29.0 & 1.68 & Normal \\
\hline 2011 & 77.3 & 8.8 & -1.00 & Moderate \\
\hline 2012 & 420.0 & 38.2 & 7.16 & Normal \\
\hline
\end{tabular}

Source Compiled by authors from Lodwar station precipitation analysis

Table 2 Livestock mortality rates associated with drought reported in the study area

\begin{tabular}{lllllll}
\hline Drought Year & SPI $^{\mathrm{a}}$ & $\begin{array}{l}\text { Drought } \\
\text { Category }\end{array}$ & Cattle (\%) & $\begin{array}{l}\text { Shoats (Goats } \\
\text { and Sheep) (\%) }\end{array}$ & Camels (\%) & Author \\
\hline $1952-1956$ & -4.47 & Extreme & $70-80$ & - & 13 & UNEP and GOK (2000) \\
$1962-1965$ & -1.87 & Severe & $30-50$ & - & - & UNEP and GOK (2000) \\
$1980-1984$ & -5.97 & Extreme & 63 & 55 & 45 & Ellis and Swift (1988), McCabe (1987) \\
$1990-1995$ & -5.24 & Extreme & 40 & 23 & 10 & Oba (2001) \\
$1999-2001$ & -5.17 & Extreme & 35 & 43 & 18 & Aklilu and Wekesa (2002) \\
$2008-2009$ & -3.16 & Extreme & 60 & 40 & - & Zwaagstra et al. (2010) \\
\hline
\end{tabular}

${ }^{a}$ Standardized precipitation index

livestock losses. Following losses during droughts, many households were able to restock their herds, while others searched for alternative livelihood activities as discussed in Sect. 4.3. Since the majority of households in the study area do not have diversified livelihood options to fall back upon, they are normally vulnerable to extreme drought events. Figure 3 gives a summary of drought impacts on pastoralists' livelihoods in Turkana County.

Other drought impacts observed by the respondents are the drying up of water sources (18\%), declining pasture availability and access (14\%), food shortages (15\%), increasing food prices $(12 \%)$, and loss of income $(10 \%)$. While the perceived impacts of drought can be numerous and far-reaching, none are more important than the drying up of water sources. Turkana is permanently under water stress, with seasonal streams and groundwater providing the county's main water supply. The majority of households at the time of interview trekked for more than $15 \mathrm{~km}$ in search of household water supplies. The recent discovery of underground water sources is, however, widely viewed by respondents as the panacea that will end Turkana's chronic water shortage. In general, the observations made by the respondents in this study confirm the findings by Nkedianye et al. (2011) that the increasing frequency and intensity of drought events are negatively impacting pastoral livelihoods and ecosystems. 
Fig. 3 Estimate of drought impact on pastoral livelihoods in Turkana. Source Compiled from field study questionnaires and graphics and images created by the corresponding author
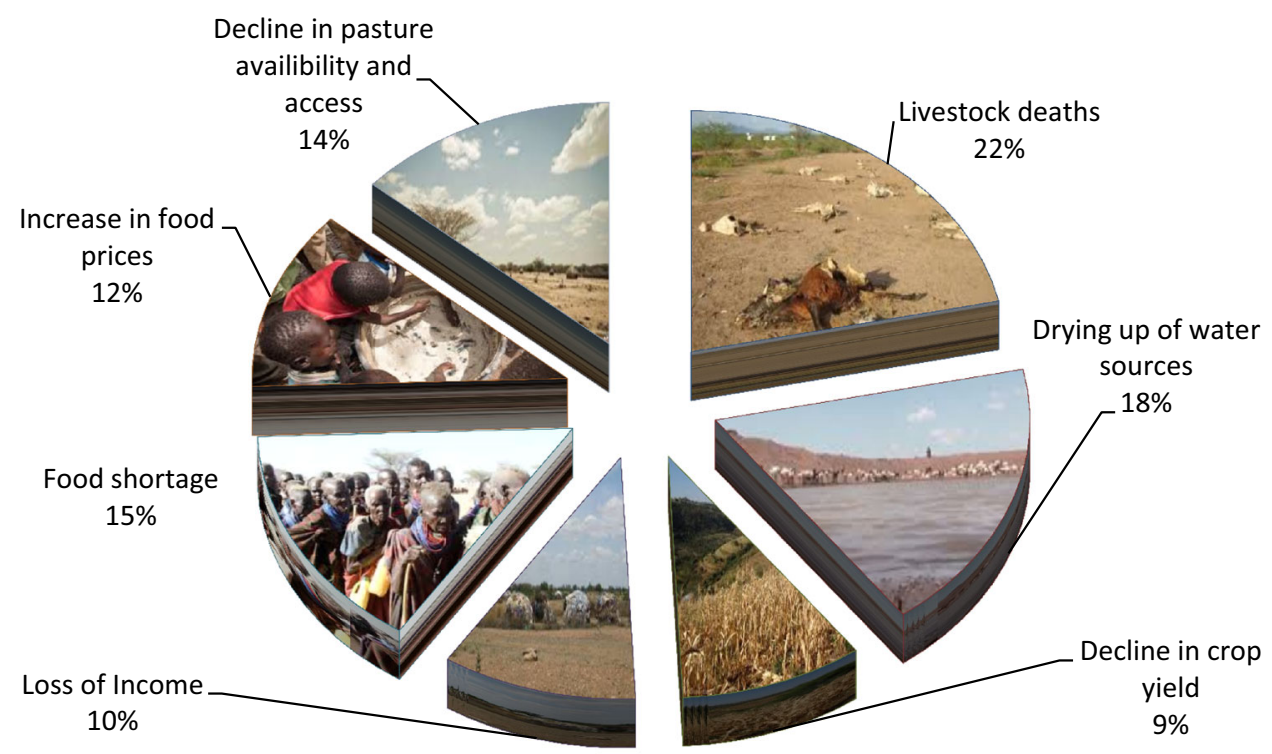

\subsection{Turkana's Adaptation and Coping Strategies to Drought}

The Turkana community has a long history of proving its ability to respond to extreme environmental conditions, despite the challenges faced with prolonged drought events (Handley 2012). This study has revealed a myriad of actions and strategies that households use to adapt to or cope with the vagaries of drought. The discussion that follows highlights some of the multiple strategies employed by the respondents in response to changing conditions. A number of constraints to the desired adaptation and coping mechanisms are also discussed in detail.

\subsubsection{Adaptation Strategies Used by Interviewed Households}

A majority of households in the study area pursue a number of adaptation strategies to mitigate the adverse impacts of drought. Figure 4 summarizes the major adaptation techniques and the percent of respondents using each strategy. The details of these key adaptive measures are explained below.

Diversification of livelihood is a major adaptation strategy practiced by more than $58 \%$ of the respondents. Due to the frequency of droughts, a majority of households around the periurban centers and along Turkwel River undertake many activities to augment resources from livestock production. In this study, livelihood diversification refers to processes by which households construct a diverse portfolio of activities and social support capabilities in their struggle for survival and in order to improve their standards of living (Ellis 1995). This implies that livelihood diversification is not synonymous with income diversification. According to Reardon and Vosti (1995), the rationale for diversification is to create a portfolio of livelihoods with different risk attributes so that drought risk can be managed in advance of moisture deficit and recovery is quicker and easier after the event. This study indicates that the majority $(81.46 \%, n=246)$ of the respondents engage in livelihood diversification activities, while a number $(35.1 \%, n=106)$ are still dependent on climate sensitive activities. These climate sensitive activities include mainly crop farming (sorghum, maize, green grams/mung beans, cowpeas, and vegetables), poultry and egg production, and aloe harvesting. The majority of respondents prefer to engage in nonclimate-sensitive activities such as microbusiness, casual labor, artisan activities, salaried fixed employment, and charcoal production. Other activities include harvesting of wild fruits for food, honey production, basket making, and handicraft products (for example baskets and brooms) crafted from the palm tree. According to key informants, most of these livelihood diversification activities are adapted to complement pastoralism, rather than to substitute for livestock production. Interestingly, Watson and van Binsbergen (2006) reported that most of these livelihood diversification activities are practiced by women in Turkana. While no gender aggregation in terms of women and men roles was analyzed in this study, other studies (Fernando 2002; Njiru 2012) have shown an increasing involvement of women in livelihood diversification in the study area.

Mobility is a well-known primary risk reduction strategy, particularly in times of drought employed by pastoralists exploiting rangelands. A majority of the respondents $(59.2 \%)$ view mobility as an adaptation strategy to reduce risk, and also to access livestock, markets, or urban centers. But the level of mobility differs 


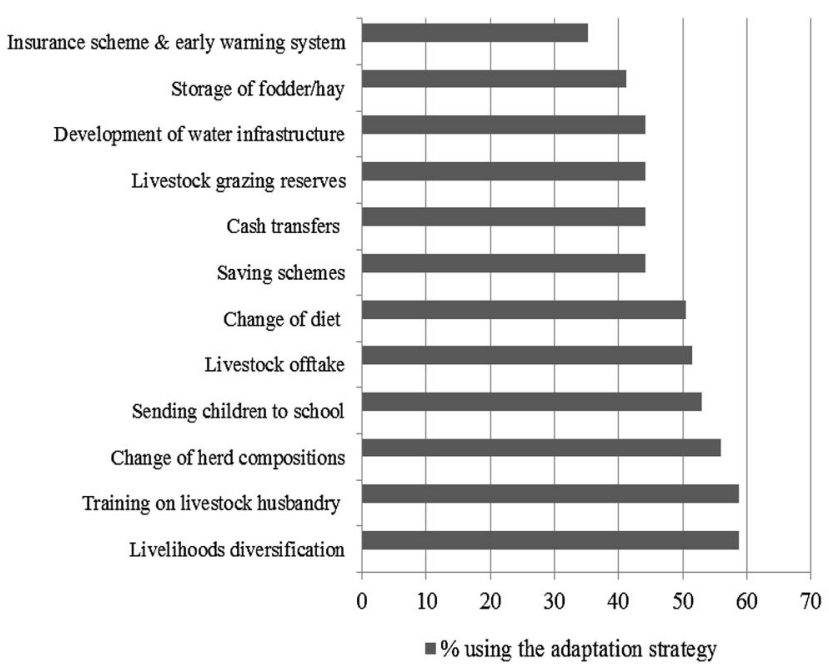

Fig. 4 Drought adaptation and coping strategies

between the surveyed locations depending on access to pasture and water resources. Discussion with key informants confirm that herd mobility enables opportunistic use of resources and helps minimize the effects of droughts, disease outbreaks, and livestock losses through raids. Turkana herders frequently migrate across borders, especially to Uganda, South Sudan, and Ethiopia, to access resources and markets. These movements are often affected by impacts such as violent conflicts, diseases outbreaks, and recurrent drought. Research shows that seasonal decisions to migrate insure that households maintain the productivity of their herds and security of their families (Ellis and Swift 1988; Little and Leslie 1999; Musembi and Kameri-Mbote 2013). This form of mobility is pursued primarily for livelihood purposes and is very strategic (McCabe 2006). Movement of livestock to areas with secure water and pasture resources is an effective strategy against droughts (Niamir-Fuller 2000) and has remained important for herders in northwestern Turkana County of Kenya.

With the recent discovery of oil in Turkana and changing land tenure systems from communal to private ownership in the rangelands, mobile pastoralism is becoming increasingly constrained (Eliza et al. 2015). Although our study did not quantify factors affecting mobility, field observations show that declining livestock mobility in the area is driven by a combination of factors, including increased individualization and disruption of social structures, increased competition and violent conflicts over resources, and lately the increased acquisition of land by investors following oil discovery. Even though most pastoralists have become increasingly semisedentary, their herds are still quite mobile. A key issue to consider in the future in order to retain mobility as an adaptation strategy will be the ability of pastoralist to continue

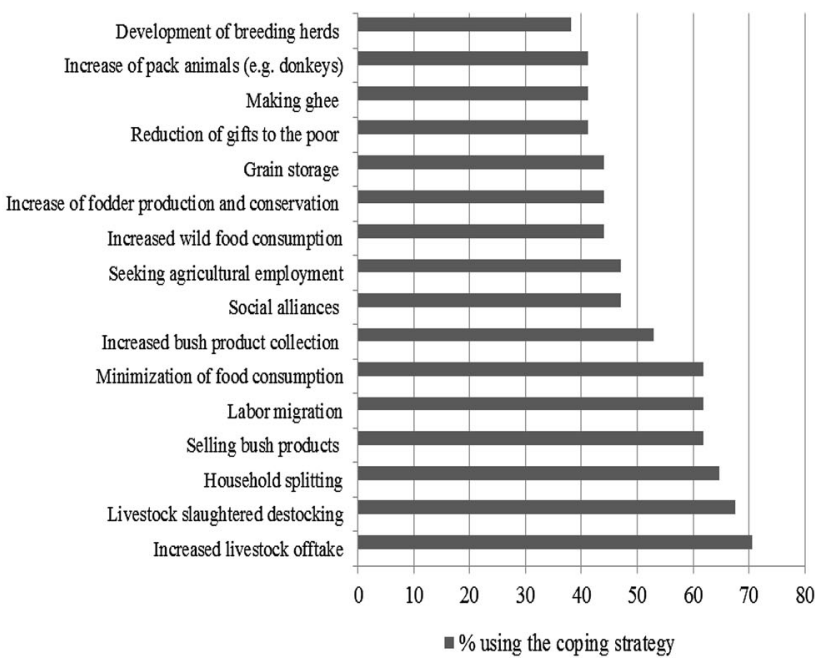

managing the rangelands at a communal scale, rather than fragmenting rangelands into private and individual tenure systems.

Training in livestock health provision was reported by respondents $(58.8 \%)$ as a strategy to reduce risks associated with recurrent drought and livestock diseases. The increased number of trained, community-based animal health workers now operating in Turkana areas is an important animal health delivery channel in this marginal area (Mugunieri et al. 2004). Of the livestock keepers who had treated their animals, $85 \%$ claimed to have gained skills, training, and knowledge from the community-based animal health workers. Traditionally the control of livestock diseases was through the use of local herbs and local techniques; these practices seem to have changed with the emergence of trained community-based animal health workers. Key informants revealed that many youth with animal health care skills are able to support their families with income earned from the sale of veterinary drugs and from attending to sick animals. But owing to the limited training and literacy of community-based animal health workers, these medical providers have been perceived by professional veterinarians and government officials as a threat to the provision of adequate animal health services (Mugunieri et al. 2004).

Diversification of herd composition and species are key strategies that have enabled pastoralism to thrive in a harsh environment for centuries (Speranza 2010). Almost $53 \%$ of the households surveyed diversify herd composition and keep a mix of livestock species that include cattle (51.2\%), shoats (sheep and goats) (88.2\%), camels (22.9\%), and donkeys (12.6\%). Livestock types consist of local breeds, mainly small East African Zebu cattle, Red Maasai sheep, and small East African goats. Households involved in diversification of herd composition and species have a 
higher off-take and thereby improved access to food during drought. Key informant discussions indicate that Turkana presently prefer goats and camels, since these species are perceived to be more resistant to drought than cattle. There is also a preference for browsers (goats and camels), and a move away from grazers (cattle and sheep), due to changes in vegetation composition and water scarcity. During drought, woody species with leafy fodder are more reliable than grasses, thus encouraging the shift away from grazing livestock. The large proportion of respondents that made a shift in livestock composition indicates that with more than one species of livestock, including cattle, herders can generate a wider variety of livestock products and make better use of the available forage in different seasons, even in times of drought. However, increasing drought frequencies are unlikely to permit sufficient fodder growth to allow for adequate accumulation of a sustainable herd size to support a household through animal products alone. Ali and Hobson (2009) contend that increased drought frequency hastens herd depletion, narrows opportunity for rapid livelihood recovery, and intensifies pressure on depleted water and pasture resources.

Sending children to school to acquire education and training is partly seen as an essential strategy to facilitate income diversification for pastoral households. Most (60\%) respondents view education as a long-term adaptation strategy. Many households believe education assists family members to find jobs in the modern sector and urban economy. Other households also send children to school to make sure that they get food through school nutritional programs. For a long time, education for pastoralists was considered by government as an exit strategy to be encouraged, and not as an end or adaptation in itself. This probably explains why pastoralist areas have had lower enrollment, retention, completion, and achievement rates than the rest of the country. Among the Turkana, only $32 \%$ of the school-age children are enrolled in schools (Migosi et al. 2012). This situation is likely to be worse when it is viewed in light of enrollment in post primary education. Households surveyed indicate that when young boys and girls go to school, there is a probability of redistribution of household tasks, including livestock herding, to parents and those children who are not able to access school. What is not clear is whether the labor lost by sending children to school is made up by other adaptation strategies. Hiring herders who have lost livestock and sending men with animals to distance pasture while women stay at home with those children who are going to school are possible options. Fratkin (1986) reported that an increase in the number of children going to school could result in a more limited family labor pool, whereas an adequate labor force is central to other adaptation and risk management strategies in pastoral areas. Our study suggests that the educational system as currently modeled in Kenya's ASALs is undermining pastoral livelihood just as much as it is seen as a successful adaptation to drought.

Livestock off-take at different stages of a drought's development is an important adaptation strategy used by pastoralists. In times of drought and food shortage, increased off-take is obligatory to meet the household's demand for food for two reasons: (1) grain is the most important source of food in domestic economy; and (2) animal sales realize some economic return from droughtcaused livestock losses that might generate no cash flow whatsoever. For years, Turkana's livestock owners were generally regarded as unmotivated by market forces by not buying when prices are low and selling when prices are high (Schilling et al. 2012). Our study indicates that $32 \%$ of the respondents sell livestock on a regular basis to have a source of cash income to cover other adaptation costs as well as to cope with short-term stresses. Pastoralists have a strong preference for holding cows for milk and calf production. Instead most respondents sold small stock, particularly goats, much more often than any other livestock type. The motivation to sell goats is the need to buy food, obtain medical care, pay school fees, and obtain cash income for other household needs. The increasing demand and price for livestock products generated by urban areas also provides another incentive for this adaptation measure. Key informants maintained that many pastoralists make use of livestock markets to off-load livestock when climatic shocks temporarily reduce the rangeland pasture and water resources needed to sustain them. These same pastoralists then use the markets to restock their herds when local rangeland conditions recover. From a policy perspective, it appears that investments in livestock marketing systems might enhance drought adaptation by increasing pastoralist marketing responsiveness to climatic variation.

\subsubsection{Coping Strategies Used by Interviewed Households}

Turkana pastoralists employ various coping responses against extreme drought events. Unlike adaptations that involve long-term shifts, coping responses are more reactive and mainly involve temporary adjustment of livelihood activities in response to drought. The sale of livestock and livestock products falls into both categories as pastoralists not only use this option to cover regular adaptation costs, but, as $70 \%$ of household survey respondents state, herders employ sales also to cope with short-term shocks. Other coping strategies to mitigate drought risk include: slaughter of old and weak livestock (68\%), splitting households into subunits located in different areas (65\%), selling bush products such as Aloe vera, wood fuel, and charcoal $(62 \%)$, searching for wage labor in towns $(62 \%)$, and minimizing food for consumption (62\%) (Fig. 4). The 
drought coping strategies reported by respondents varied from household to household based on socioeconomic and demographic characteristics.

Some pastoralist coping responses to drought are reactive and mainly involve intensive exploitation of scarce tree and pasture resources. For example, overexploitation of these resources through wood fuel collection and charcoal production are among the major causes of rangeland degradation in the study area. The focus group discussions (FGDs) revealed that the sale of charcoal and firewood, which is considered labor intensive and environmentally destructive, was a coping strategy mainly for poorer households. The study revealed that wood-based fuel production is labor intensive and environmentally destructive. Households engaging in these activities are those that are settled near the urban areas or around refugee camps in Kakuma, which provide a market for wood fuel and charcoal. Although not the best strategy for many of the key informants interviewed in Turkana, Watson and Binsbergen (2006) noted that sale of charcoal was increasingly becoming one of the ways pastoralists diversify incomes and pool resources during drought.

Proactive responses such as selling of livestock before drought are strategies practiced by the majority $(79 \%)$ of respondents. The prevalence of the practice contradicts the conventional view that pastoralists do not sell their livestock before drought. The household interviews indicate that recent awareness and capacity-building initiatives from various nongovernmental organizations and government agencies led most of the pastoralists to embrace livestock off-take for long-term resilience to drought. Although still very reactive as indicated in the FGDs, the increased local market demand for livestock and livestock products is one of the main drivers of increased off-take. But households that did not dispose of their livestock before or during a drought gave two reasons for their market inactivity: (1) the low livestock prices offered before and during drought periods; and (2) the high postdrought livestock prices that make restocking expensive for most households. Livestock prices tend to be low during drought periods because the livestock is already weak and the supply is higher than the demand. The higher prices after a drought period can be explained by the demand exceeding the supply of healthy livestock (Schilling et al. 2012).

Further analysis shows that of the 18 coping strategies practiced by respondents, 15 strategies are practiced during drought periods and for more than a month ( $>1$ month) as

Table 3 Coping strategies differentiated by periods when used and the duration of use by respondents

\begin{tabular}{|c|c|c|c|c|c|c|c|}
\hline \multirow[t]{2}{*}{ Coping strategy } & \multicolumn{3}{|c|}{$\begin{array}{l}\text { Period when strategy is used } \\
\text { (\% of respondents) }\end{array}$} & \multicolumn{4}{|c|}{$\begin{array}{l}\text { How long strategy is used } \\
\text { (\% of respondents) }\end{array}$} \\
\hline & $\begin{array}{l}\text { Before } \\
\text { drought }\end{array}$ & $\begin{array}{l}\text { During } \\
\text { drought }\end{array}$ & $\begin{array}{l}\text { After } \\
\text { drought }\end{array}$ & 1 month & $>1$ month & 1 year & $>1$ year \\
\hline Increased livestock and livestock product sales & 79.2 & 16.7 & 4.2 & 21.7 & 69.6 & 8.7 & 0 \\
\hline Old/weak livestock slaughtered for consumption & 0 & 100 & 0 & 33.3 & 58.3 & 4.2 & 4.2 \\
\hline Labor migration to towns & 4.8 & 90.5 & 4.8 & 15 & 65 & 5 & 15 \\
\hline Household splitting (e.g. sending children to relatives) & 9.1 & 77.3 & 13.6 & 22.2 & 72.2 & 0 & 5.6 \\
\hline Seeking agricultural employment & 62.5 & 18.8 & 18.8 & 21.4 & 71.4 & 7.1 & 0 \\
\hline Opportunity to do so e.g. selling bush products and labor & 14.3 & 42.9 & 42.9 & 21.1 & 68.4 & 5.3 & 5.3 \\
\hline Increased bush/wild product collection and sale & 38.9 & 55.6 & 5.6 & 26.3 & 63.2 & 5.3 & 5.3 \\
\hline Livestock migration/herd splitting & 8 & 88 & 4 & 9.1 & 77.3 & 4.5 & 9.1 \\
\hline $\begin{array}{l}\text { Minimization of food consumption, reduction of meals and } \\
\text { expenses }\end{array}$ & 0 & 95.2 & 4.8 & 33.3 & 57.1 & 4.8 & 4.8 \\
\hline Reduction of gifts to the poor by richer households & 0 & 78.6 & 21.4 & 8.3 & 83.3 & 8.3 & 0 \\
\hline Increased wild food consumption & 20 & 73.3 & 6.7 & 25 & 62.5 & 0 & 12.5 \\
\hline Seeking relief assistance & 4.2 & 91.7 & 4.2 & 14.3 & 19 & 9.5 & 57.1 \\
\hline Grain/fodder storage (mainly for wealthier households) & 73.3 & 13.3 & 13.3 & 23.5 & 64.7 & 0 & 11.8 \\
\hline Social support systems (social alliances e.g. stock friendship) & 31.2 & 50 & 18.8 & 22.2 & 66.7 & 5.6 & 5.6 \\
\hline Making ghee for the dry season & 78.6 & 7.1 & 14.3 & 7.1 & 64.3 & 21.4 & 7.1 \\
\hline Increase of pack animals (draught animals e.g. donkeys) & 100 & 0 & 0 & 21.4 & 7.1 & 7.1 & 64.3 \\
\hline $\begin{array}{l}\text { Increase of fodder production and conservation to replace lost } \\
\text { access to dry season grazing areas }\end{array}$ & 86.7 & 0 & 13.3 & 0 & 73.3 & 26.7 & 0 \\
\hline $\begin{array}{l}\text { Development and sustaining of breeding herds and sale of other } \\
\text { stock to increase resilience }\end{array}$ & 53.8 & 0 & 46.2 & 7.1 & 35.7 & 28.6 & 28.6 \\
\hline
\end{tabular}


shown in Table 3. Despite the challenges faced by practitioners of the coping measures used in the study area, they help households to buffer the adverse effects of droughts. The dynamic changes observed among the interviewed households in terms of coping mechanisms show the drought resilience potential of the Turkana community in the face of changing climatic conditions.

\subsection{Constraints to the Adaptation and Coping Strategies}

The desired adaptation strategies proposed by the majority of respondents include establishing strategic livestock feed reserves, irrigation farming, development of water sources and insurance for livestock, and saving schemes. Many respondents also expressed interest in establishing grain and fodder storage facilities, improving livestock breeds, making livestock products such as ghee for sale during the dry season, and increasing their herd size. The adaptation and coping strategies desired by the households are not without constraints. Respondents reported a number of limitations to their strategies, which include inadequate cash income and capital (46\%), insecurity (50\%), lack of affordable credit facilities and access (42\%), illiteracy and lack of technical knowledge ( $25 \%)$, inadequate markets $(10 \%)$, and lack of inputs and equipment for agricultural practices $(22 \%)$.

Further probing with FGDs participants revealed that some of these desired strategies, such as irrigation farming, development of water sources, and insurance for livestock assets, require an initial investment capital that is beyond the reach of many households. Similarly, although many households are interested in grain and fodder storage facilities, few would be interested in investing in these facilities bacause of pasture scarcity in the study area. While improved livestock breeds were mentioned as a desired effective adaptation measure to drought, access to livestock breeds and suitable veterinary services are problematic, because of financial constraints, the poor social and economic status of most households, and infrastructural challenges such as poorly developed markets in Turkana.

Insecurity and conflicts associated with livestock raids are also major constriants to some of the desired adaptation and coping responses in the study area. A study by Schilling et al. (2012) contended that violent conflicts in Turkana, if not managed, are likely to undermine the gains made so far in supporting the adaptation program in the area (see also Scheffran et al. 2014). Survey respondents indicated that water and pasture resources can only be accessed in areas with security. More emphases on peacebuilding initiativesis are needed in conflict hot spots along the borders of Turkana to promote effective adaptation stratagies. Similary, investment in education to improve literacy levels, which is a major constraint to many desired adaptations, are key in addressing cyclic drought vulnerability in the area. Furthermore, respondents highlighted the crucial role of local governance (e.g. chiefs) and informal institutions (e.g. council of elders), political leadership (e.g. members of pariliament and County Assembly), and administrative structures (e.g. police) in improving market access and upholding the rule of law in Turkana. Lack of access to affordable credit facilities was frequently mentioned by FGDs respondents as the single most significant constraint to desired adaptation and coping strategies that they identified as feasible. Credit and banking facilities are only found in the towns of Lokichogio and Lodwar, which according to household respondents are only accessible to established members of the business community and a few livestock traders. Banking based on mobile phones is increasingly becoming a common and well-developed service in the area. Results showed that households are slowly embracing mobile phones for receiving cash remittences through the M-pesa system from relatives in urban centers. So far mobile phones are not used by many respondents because of the poor network coverage in Turkana. As part of the oil exploration process, network coverage is likely to improve, and will possibly offer pastoralists better access to banking options in the future.

The majority of constraints to adaptation and coping strategies are driven by the low level of development in Turkana which in turn is the result of a long history of political and socioeconomic marginalization by the central government (Schilling and Remling 2011). In October 2012, the Government of Kenya adopted the National Policy for the Sustainable Development of Northern Kenya and Other Arid Lands. The policy is an important document for three reasons. First, it acknowledges marginalization and misperceptions of pastoralism by the government. "Pastoralists are among the groups most marginalised from socioeconomic services and infrastructure"(Kenya ASAL Policy 2012, p. 5). Second, the policy expresses a clear shift in perception towards recognizing "the strengths of pastoralism and $[\ldots]$ the contribution of pastoralism to food security, environmental stewardship, and economic growth" (Kenya ASAL Policy 2012). And third, the policy identifies critical deficiencies and measures to address them. While privileging the role of traditional pastoral governance systems, the policy advocates strengthening national integration, cohesion, and equity by improving infrastructure, human capital, security, and the rule of law (Odhiambo 2013). To date considerable progress has been made on the implimentation of the ASAL policy, which will go a long way to reduce marginalization of pastoral communities and to decrease constraints to their adaptation to extreme climate variability and change. The 
most meangful immediate progress is the growth of national and county level structures to end drought emergenices in the ASALs.

\section{Conclusions}

The impact of drought among pastoral communities normally manifests itself in the form of livestock losses, which adversely affects the provision of subsistence, income, and other sociocultural goods and services to a pastoral household. In Turkana County, pastoral households are already taking measures to protect their livelihoods against the increase in drought events. Most of the adaptive and coping strategies to drought are rather reactive and mainly intensify exploitation of existing resources, which may in turn undermine the very livelihoods that they are meant to complement. Existing opportunities for long-term adaptation strategies to drought appear constrained by a number of socioeconomic developments, political changes, and deteriorating ecological conditions. For example, violent conflicts, lack of affordable credit facilities and financial services, limited access to markets, recently observed land tenure changes from communal to private ownership following oil discovery, and poor infrastructure are problematic to sustainable pastoral production system. Other constraints are inadequate access to professional veterinary services, degradation of grazing lands, and poor information access and extension services. The increasing frequency of droughts allows limited recovery periods for pastoral households, and, if the trend continues, the recovery periods may become even shorter thereby undermining the resilience of both pastoral ecosystems and livelihoods. Therefore, proactive measures aimed at sustainable protection of the main productive assets, such as pastures and livestock resources, are essential. Pastoral viability is best attained by guaranteeing free and safe livestock mobility, improving the provision of security, increasing access to education, livestock markets, and expanding transport and communication infrastructure. These efforts would be most effective if supported by programs offering affordable credit facilities, strengthening extension services, promoting diversification of livelihoods and income sources, and enhancing livestock diversity and promoting species that are drought tolerant. Herd diversification needs to be given attention in view of the contemporary ecological trends that tend to favor woody species compared to grasses. This implies that browsers, especially goats and camels, may become increasingly suitable for the area in the face of increasing frequency and severity of droughts. This article concludes that although the adaptation and coping strategies employed by households in Turkana are specific to their context, the information generated about resource use is an important tool with which to guide development and policy processes at both local and national levels.

Acknowledgments This study was funded by African Climate Change Fellowship Program, Global Change for System Analysis, Research \& Training-ACCFP/START, and additional support from the Red Cross/Red Crescent Climate Center/START and United Nations International Strategy for Disaster Reduction (UNISDR) under Climate and Development Knowledge Network small grant.

Open Access This article is distributed under the terms of the Creative Commons Attribution 4.0 International License (http://crea tivecommons.org/licenses/by/4.0/), which permits unrestricted use, distribution, and reproduction in any medium, provided you give appropriate credit to the original author(s) and the source, provide a link to the Creative Commons license, and indicate if changes were made.

\section{References}

Abawi, Y., S. Dutta and J. Ritchie. 2003. Potential use of climate forecasts in water resources management. In Science for drought: Proceedings of the National Drought Forum at Brisbane, Australia, ed. R. Stone and I. Patridge, 78-81. Department of Primary Industries, Queensland.

Adger, N., S. Agrawala, M.M.Q. Mirza, C. Conde, K. O’Brien, J. Pulhin, R. Pulwarty, B. Smit, and T. Takahashi. 2007. Assessment of adaptation practices, options, constraints and capacity. In Climate change 2007: Impacts, adaptation and vulnerability. Contribution of Working Group II to the fourth assessment report of the Intergovernmental Panel on Climate Change, ed. M.L. Parry, O.F. Canziani, J.P. Palutikof, P.J. van der Linden, and C.E. Hanson, 717-743. Cambridge, U.K.: Cambridge University Press.

African Union. 2010. Policy framework for pastoralism in Africa. Addis Ababa: African Union.

Aklilu, Y., and M. Wekesa 2002. Drought, livestock and livelihoods: Lessons from the 1999-2001 emergency response in the pastoral sector in Kenya. Humanitarian Practice Network, Overseas Development Institute, London.

Ali, A., and M. Hobson. 2009. Social protection in pastoral areas. Humanitarian Policy Group. Overseas Development Institute, London.

Anyamba, A., and C.J. Tucker. 2001. NDVI anomaly patterns over Africa during the 1997/98 ENSO warm event. International Journal of Remote Sensing 22(10): 1847-1859.

Below, T., A. Artner, R. Siebert, and S. Sieber. 2010. Micro-level practices to adapt to climate change for African small scale farmers: A review of selected literature. The International Food Policy Research Institute (IFPRI) Discussion Paper, 953.

Bett, B., C. Jost, R. Allport, and J. Mariner. 2009. Using participatory epidemiological techniques to estimate the relative incidence and impact on livelihoods of livestock diseases amongst nomadic pastoralists in Turkana South District, Kenya. Preventive Veterinary Medicine 90(34): 194-203.

Blaikie, P., T. Cannon, I. Davis, and B. Wisner. 1994. At risk: Natural hazards, people's vulnerability and disasters. London: Routledge.

Blench, R. 2000. Extensive pastoral livestock systems: Issues and options for the future. GCP/JPN/005/JPN. Rome: Food and Agriculture Organization. 
Brooks, N., W.N. Adger, and P.M. Kelly. 2005. The determinants of vulnerability and adaptive capacity at the national level and the implications for adaptation. Global Environmental Change 15(2): 151-163.

Campbell, D.J. 1999. Response to drought among farmers and herders in southern Kajiado district, Kenya: A comparison of 1972-1976 and 1994-1995. Human Ecology 27(3): 377-416.

Catley, A., B. Admassu, G. Bekele, and D Abebe. 2014. Livestock mortality in pastoralist herds in Ethiopia and implications for drought response. Disasters 38(3): 500-516.

Coughenour, M.B., and J.E. Ellis. 1993. Landscape and climatic control of woody vegetation in a dry tropical ecosystem: Turkana District, Kenya. Journal of Biogeography 20(4): 383-398.

Douville, H. 2003. Assessing the influence of soil moisture on seasonal climate variability with AGCMs. Journal of Hydrometeorology 4(6): 1044-1066.

Downing, T.E., and K. Bakker. 2000. Drought discourse and vulnerability. In Drought: A global assessment. Natural hazards and disasters series, Vol. II, ed. D.A. Wilhite, Chapter 45: 3-18. London: Routledge.

Eliza, M.J., C.Z. Leo, and E. Kalipeni. 2015. Oil discovery in Turkana County, Kenya: A source of conflict or development? African Geographical Review 34(2): 142-164.

Ellis, J.E 1995. Climate variability and complex ecosystem dynamics: Implications for pastoral development. In Living with uncertainty: New direction in pastoral development in Africa, ed. I. Scoones, 37-46. London: Intermediate Technology Publications.

Ellis, J.E., and D.M. Swift. 1988. Stability of African pastoral ecosystems: Alternate paradigms and implications for development. Journal of Range Management 41(6): 450-459.

Eriksen, S.H., K. Brown, and P.M. Kelly. 2005. The dynamics of vulnerability: Locating coping strategies in Kenya and Tanzania. The Geographical Journal 171(4): 287-305.

Fernando, P. 2002. Donkeys and development-Socio-economic issues in the use and management of donkeys. http://www.dfid. gov.uk/R4D//PDF/Outputs/R7350f.pdf. Accessed 20 Aug 2013.

Fratkin, E. 1986. Stability and resilience in East African pastoralism: The Ariaal and Rendille of northern Kenya. Human Ecology 14(3): 269-286.

Giddings, L., M. Soto, B.M. Rutherford, and A. Maarouf. 2005. Standardized precipitation index for Mexico. Atmosfera 18(1): $33-56$.

Gulliver, P.H. 1955. The family herds: A study of two pastoral tribes in East Africa, the Jie and Turkana. London: Routledge \& K. Paul.

Handley, C.S. 2012. No one can kill the drought: Understanding complexity in the relationship between drought and conflict amongst pastoralists in northern Kenya. Durham theses, Durham University.

Howden, D. 2009. The great drought in East Africa. No rainfall for three years. http://www.infiniteunknown.net/2009/10/03/the great-drought-in-east-africa-no-rainfall-for-three-years/gov/ fews/africa/index.php. Accessed 16 Nov 2014.

Huho, J.M., and E.M. Mugalavai. 2010. The effects of droughts on food security in Kenya. The International Journal of Climate Change Impacts Response 2(2): 61-72.

Hounam, C.E., J.J. Burgos, M.S. Kalik, W.C. Palmer, and J. Rodda. 1975. Drought and agriculture. Report of the CAgM Working Group on Assessment of Drought. Technical Note No. 138. WMO Publication No. 392. Geneva.

IPCC (Intergovernmental Panel on Climate Change). 2001. Climate change 2001: Impacts, adaptation and vulnerability. Contribution of Working Group II to the third assessment report of the IPCC. Cambridge: Cambridge University Press.
IPCC (Intergovernmental Panel on Climate Change). 2007. Climate change 2007: Impacts, adaptation and vulnerability. Contribution of Working Group II to the fourth assessment report of the Intergovernmental panel on climate change. Cambridge: Cambridge University Press.

IPCC (Intergovernmental Panel on Climate Change). 2012. Managing the risks of extreme events and disasters to advance climate change adaptation. A special report of Working Groups I and II of the Intergovernmental Panel on Climate Change. Cambridge: Cambridge University Press.

Jaetzold, R., and H. Schmidt. 1983. Farm management handbook of Kenya. Volume II. Parts A, B and C. Ministry of Agriculture in Cooperation with German Agency for Technical Cooperation, Nairobi.

Kameri-Mbote, P. 2013. Preface: Securing the land and resource rights of pastoral peoples in East Africa. Nomadic Peoples 17(1): $1-4$.

Kariuki, J.G., J.M. Machua, A.M. Luvanda, and J.N. Kigomo. 2008. Baseline survey of woodland utilization and degradation around Kakuma refugee camp. KEFRI (Kenya Forestry Research Institute), Project Technical Report No. 1.

Kenya ASAL Policy. 2012. National policy for the sustainable development of northern Kenya and other arid lands. Sessional paper No. 8 of 2012, Nairobi, Republic of Kenya.

Kenya Meteorological Service. 2010. Review of the weather in JuneJuly-August (JJA) 2010 seasons and the outlook for the October-November-December 2010 "short rains" season. Kenya Meteorological Service, Nairobi.

Kenya National Bureau of Statistics. 2010. The 2009 population and housing census report. The Kenya National Bureau of Statistics, Government Printers, Nairobi.

Little, P.D. 2003. Pastoral ecologies: Rethinking interdisciplinary paradigms and the political ecology of pastoralism in East Africa. In African savannas: Global narratives and local knowledge of environmental change, ed. T.J. Bassett, and D. Crummey, 161-177. Oxford: James Currey.

Little, M.A., and P.W. Leslie (eds.). 1999. Turkana herders of the dry savanna: Ecology and biobehavioral response of nomads to an uncertain environment. New York: Oxford University Press.

Maundu, P., S. Kibet, Y. Morimoto, M. Imbumi, and R. Deka. 2009. Impact of Prosopis juliflora on Kenya's semi-arid and arid ecosystems and local livelihoods. Biodiversity 10(2-3): 33-50.

McCabe, J.T. 1987. Drought and recovery: Livestock dynamics among the Ngisonyoka Turkana of Kenya. Human Ecology 15(4): 371-389.

McCabe, J.T. 2006. Cattle bring us to our enemies. Turkana ecology, politics, and raiding in a disequilibrium system. Human Ecology 34(1): 147-149.

McGahey, D., J. Davies, and E. Barrow. 2008. Pastoralism as conservation in the Horn of Africa: Effective policies for conservation outcomes in the drylands of Eastern Africa. Annals of Arid Zones 46(2): 353-377.

Migosi, J., D. Nanok, C. Ombuki, and J. Metet. 2012. Trends in primary school dropout and completion rates in the pastoralist Turkana County, Kenya. Universal Journal of Education and General Studies 1(10): 331-338.

Mugunieri, G.L., P. Irungu, and J.M. Omiti. 2004. Performance of community-based animal health workers in the delivery of livestock health services. Tropical Animal Health and Production 36(6): 523-535.

Musembi, C.N., and P. Kameri-Mbote. 2013. Mobility, marginality and tenure transformation in Kenya: Explorations of community property rights in law and practice. Nomadic Peoples 17(1): 5-32.

Niamir-Fuller, M. 2000. Managing mobility in African rangelands. In Proceedings of the international symposium on property rights, 
risks, and livestock development in Sub-Saharan Africa, ed. N. McCarthy, B. Swallow, M. Kirk and P. Hazell, 102-131. International Food Policy Research Institute, Washington, DC/ International Livestock Research Institute, Nairobi.

Nicholson, S.E. 2014. A detailed look at the recent drought situation in the Greater Horn of Africa. Journal of Arid Environments 103(1): 71-79.

Njiru, B.N. 2012. Climate change, resource competition, and conflict amongst pastoral communities in Kenya. In Climate change, human security and violent conflict. Hexagon series on human and environmental security and peace, ed. J. Scheffran, M. Brzoska, H.G. Brauch, P.M. Link, and J. Schilling, 513-527. Berlin: Springer.

Nkedianye, D., J. de Leeuw, J.O. Ogutu, M.Y. Said, T.L. Saidimu, S.C. Kifugo, D.S. Kaelo, and R.S. Reid. 2011. Mobility and livestock mortality in communally used pastoral areas: The impact of the 2005-2006 droughts on livestock mortality in Maasailand. Pastoralism: Research, Policy and Practice 1(17): $1-17$.

Notenbaert, A., P. Thornton, and M. Herrero. 2007. Livestock development and climate change in Turkana District, Kenya. Discussion paper No. 7-Targeting and innovation. International Livestock Research institute (ILRI), Nairobi.

Notenbaert, A., J. Davies, J. De Leeuw, M. Said, M. Herrero, P. Manzano, M. Waithaka, A. Aboud, and S. Omondi. 2012. Policies in support of pastoralism and biodiversity in the heterogeneous drylands of East Africa. Pastoralism: Research, Policy and Practice 2(4): 1-17.

Oba, P.G. 2001. The effect of multiple droughts on cattle in Obbu, northern Kenya. Journal of Arid Environments 49(2): 375-386.

Odhiambo, M.O. 2013. The ASAL policy of Kenya: Releasing the full potential of arid and semi-arid lands-An analytical review. Nomadic Peoples 17(1): 158-165.

Opiyo, F. 2012. Protect Turkana land from speculators. Standard Newspaper. http://www.standardmedia.co.ke/article/ 2000055665/protect-turkana-land-from-speculators. Accessed 12 April 2012.

Opiyo, F.E.O., O.V. Wasonga, and M.M. Nyangito. 2014. Measuring household vulnerability to climate-induced stresses in pastoral rangelands of Kenya: Implications for resilience programming. Pastoralism: Research, Policy and Practice 4(10): 1-15.

Osano, P.M., M.Y. Said, J. De Leeuw, S.S. Moiko, D.O. Kaelo, S. Schomers, R. Birner, and J.O. Ogutu. 2013. Pastoralism and ecosystem-based adaptation in Kenyan Maasailand. International Journal of Climate Change Strategies and Management 5(2): 198-214.

Reardon, T., and S.A. Vosti. 1995. Links between rural poverty and the environment in developing countries: Asset categories and investment poverty. World Development 23(9): 1495-1506.

Saitoti, T.O. 1986. The worlds of a Maasai warrior: An autobiography. Berkeley: University of California.

Scheffran, J., T. Ide, and J. Schilling. 2014. Violent climate or climate of violence? Concepts and relations with focus on Kenya and Sudan. The International Journal of Human Rights 18(3): 369-390.

Schilling, J. and E. Remling. 2011. Local adaptation and national climate change policy in Kenya: Discrepancies, options, and the way forward. Universität Hamburg, Research Group Climate Change and Security (CLISEC), Germany.

Schilling, J., F.E.O. Opiyo, and J. Scheffran. 2012. Raiding pastoral livelihoods: Motives and effects of violent conflict in northwestern Kenya. Pastoralism: Research, Policy and Practice 2(25): $1-16$

Schilling, J., M. Akuno, J. Scheffran, and T. Weinzierl. 2014. On raids and relations: Climate change, pastoral conflict and adaptation in northwestern Kenya. In Conflict-sensitive adaptation to climate change in Africa? ed. S. Bronkhorst and U. Bob, 241-268. Berlin: Berliner Wissenschaftsverlag.

Silvestri, S., E, Bryan, C. Ringler, M. Herrero, and B. Okoba. 2012. Climate change perception and adaptation of agro-pastoral communities in Kenya. Regional Environmental Change 12(4):791-802.

Speranza, C.I. 2010. Drought coping and adaptation strategies: Understanding adaptations to climate change in agro-pastoral livestock production in Makueni District, Kenya. European Journal of Development Research 22(5): 623-642.

StataCorp. 2013. Stata statistical software: Release 13. College Station, TX: StataCorp LP.

Swift, J. 2001. District-level drought contingency planning in arid district of Kenya. In Pastoralism, drought and planning: Lessons from northern Kenya and elsewhere, ed. J. Morton, 40-84. Chatham: Natural Resources Institute.

Thornton, P., and L. Lipper. 2014. How does climate change alter agricultural strategies to support food security? The International Food Policy Research Institute (IFPRI), Discussion paper 01340.

Thornton, P.K., and P. Gerber. 2010. Climate change and the growth of the livestock sector in developing countries. Mitigation and Adaptation Strategic for Global Change 15(2): 169-184.

UNEP and GOK (United Nations Environmental Programme and Government of Kenya). 2000. Devastating drought in Kenya, environmental impacts and responses. Nairobi.

Watson, D., and J. van Binsbergen. 2006. Life beyond pastoralism: Livelihood diversification opportunities for pastoralists in Turkana District, Kenya. ILRI (International Livestock Research Institute) brief 3. Nairobi.

Whetherald, R.T., and S. Manabe. 2002. Simulation of hydrologic changes associated with global warming. Journal of Geophysical Research 107(D19): 4379-4394.

Wilhite, D.A. 2000. Drought as a natural hazard: Concepts and definitions. In Drought: A global assessment. Natural hazards and disasters series, ed. D.A. Wilhite, 245-255. London: Routledge.

Wilhite, D.A., and M.H. Glantz. 1985. Understanding the drought phenomenon: The role of definitions. Water International 10(3): $111-120$.

WMO (World Meteorological Organization). 2009. Guidelines on analysis of extremes in a changing climate in support of informed decisions for adaptation. Climate data and monitoring. WCDMP-No. 72.

Zwaagstra, L., Z. Sharif, A. Wambile, J. de Leeuw, M.Y. Said, N. Johnson, J. Njuki, P. Ericksen, and M. Herrero. 2010. An assessment of the response to the 2008-2009 drought in Kenya. A report to the European Union Delegation to the Republic of Kenya. ILRI, (International Livestock Research Institute), Nairobi. 